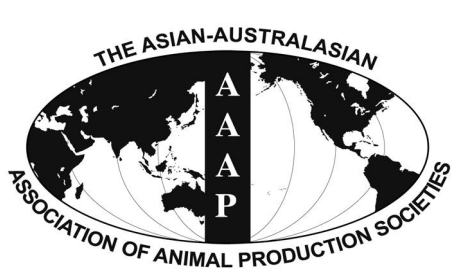

Open Access

Asian Australas. J. Anim. Sci.

Vol. 28, No. 12 : 1767-1773 December 2015

http://dx.doi.org/10.5713/ajas.15.0152

www.ajas.info

pISSN 1011-2367 elSSN 1976-5517

\title{
Effects of Water-misting Sprays with Forced Ventilation after Transport during Summer on Meat Quality, Stress Parameters, Glycolytic Potential and Microstructures of Muscle in Broilers
}

\author{
N. N. Jiang, T. Xing, P. Wang, C. Xie, and X. L. Xu* \\ Key Laboratory of Meat Processing and Quality Control, Ministry of Education China, \\ Synergetic Innovation Center of Food Safety and Nutrition, College of Food Science and Technology, \\ Nanjing Agricultural University, Nanjing 210095, China
}

\begin{abstract}
Effects of water-misting sprays with forced ventilation after transport during summer on meat quality, stress parameters, glycolytic potential and microstructures of muscle in broilers were investigated. A total of 105 mixed-sex Arbor Acres broilers were divided into three treatment groups: i) 45-min transport without rest (T group), ii) 45-min transport with 1-h rest (TR group), iii) 45-min transport with 15-min water-misting sprays with forced ventilation and 45-min rest (TWFR group). The results showed the TWFR group significantly increased $(\mathrm{p}<0.05)$ initial muscle $\mathrm{pH}\left(\mathrm{pH}_{\mathrm{i}}\right)$ and ultimate $\mathrm{pH}\left(\mathrm{pH}_{\mathrm{u}}\right)$ and significantly reduced $\mathrm{L}^{*}(\mathrm{p}<0.05)$, drip loss, cook loss, creatine kinase, lactate dehydrogenase activity, plasma glucose content, lactate and glycolytic potential when compared with other groups. Microstructure of the muscle from TWFR group broilers under light microscopy showed smaller intercellular spaces among muscle fibers and bundles compared with $\mathrm{T}$ group. In conclusion this study indicated water-misting sprays with forced ventilation after transport could relieve the stress caused by transport under high temperature, which was favorable for the broilers' welfare. Furthermore, water-misting sprays with forced ventilation after transport slowed down the postmortem glycolysis rate and inhibited the occurrence of PSE-like meat in broilers. Although rest after transport could also improve the meat quality, the effect was not as significant as watermisting sprays with forced ventilation after transport. (Key Words: Water-misting Sprays with Forced Ventilation, Stress, Glycolytic Potential, Muscle Structure, Broiler)
\end{abstract}

\section{INTRODUCTION}

All poultry species and major breeds employed in the main intensive production systems are transported at least twice during their lifetimes over distances that may range from a few kilometers to others with durations of many hours (Mitchell and Kettlewell, 2009). During transportation, there are a number of factors that initiate stress such as loading, unloading, penning in a new and unfamiliar environments, as well as confinement with and without motion vibrations, changes in temperature and humidity, inadequate ventilation and often deprivation of

\footnotetext{
* Corresponding Author: X. L. Xu. Fax: +86-25-84395939, E-mail: xlxu@njau.edu.cn

Submitted Feb. 21, 2015; Revised Apr. 9, 2015; Accepted May 7, 2015
}

food and water (Fazio and Ferlazzo, 2003). Transportation of broilers under high temperature conditions has been found to be severely stressful. Heat stress has been reported to accelerate the rate and extent of rigor mortis development, postmortem glycolysis in muscle, resulting in undesirable changes in meat characteristics, such as a condition known as pale, soft and exudative (PSE) meat (Sams, 1999). We therefore need to solve this meat quality deterioration caused by transport stress during summer periods. Although much research has been done to address this problem, including genetic selection (Yunis and Cahaner, 1999), feed modification (Daghir, 2009), physiologic adaptation and environmental modifications (Turner et al., 1997). These cannot always be readily applied in a timely manner, and essentially, the only option is that of environmental control. In order to maintain a comfortable environment for the 
animals during summer and to prevent thermal stress just prior to killing, it is a common practice to subject the birds to water shower sprays immediately following transport. Guarnieri et al. (2003) found that pre-slaughter handling with water shower spray prevented PSE condition in broiler breast meat. However there is limited data on the combined effects of water-misting sprays with forced ventilation on broilers after transport during the summer season.

Therefore, the aim of this study was to evaluate the effects of water-misting sprays with forced ventilation after transport during summer on meat quality, stress parameters, glycolytic potential and microstructures of muscle in broilers.

\section{MATERIALS AND METHODS}

\section{Experimental design}

Specification of shed containing water-misting sprays with forced ventilation shed: The layout of the shed housing the water-misting sprays with forced ventilation (Figure 1) was built according to the following specifications: width 5 m; length $12 \mathrm{~m}$; height $4.5 \mathrm{~m}$; giving an enclosed area 60 $\mathrm{m}^{2}$.

Ventilation system: Forced ventilation in the shed was provided by six fans supplying a total output of $3,265 \mathrm{~m}^{3} / \mathrm{h}$; three fans in each wall. Each fan has rainproof cover. The roof had a single exhaust fan.

Water-misting sprays system: Water-misting sprays was provided by a high pressure pump. The system comprised of a pressure adjustment valve, fine filters for the incoming water, nozzles fitted to appropriate pipe work to allow uniform distribution of water through the sprays. The system has six sprinkle-nozzles, three in each walls. This system allowed the use of $0.05 \mathrm{~mm}$ water-misting sprays operating at a pressure of $0.6 \mathrm{MPa}$.

\section{Treatment arrangement}

The experimental trials were conducted in one processing plant in Jiangsu, China during the summer months, usually around midday. A total of 105 live, $45 \mathrm{~d}$ old, mixed-sex Arbor Acres broilers were obtained from a commercial plant. The average weight of bird was $2.5 \mathrm{~kg}$ and they were randomly assigned into three treatment groups, as follows: i) 45-min transport without rest ( $\mathrm{T}$ group), ii) 45-min transport with $1 \mathrm{~h}$ rest (TR group), iii) 45-min transport with 15-min water-misting sprays with forced ventilation and 45-min rest (TWFR group). Each group consisted of 7 birds with 5 replicates. All procedures were approved by the Animal Care and Use Committee of the Food Science College of Nanjing Agricultural University. Feed and water were removed from the birds $8 \mathrm{~h}$ prior to transport, and no feed or water was supplied during the transport and recovery periods.

All broilers were transported in a truck for $45 \mathrm{~min}$ from the farm to the abattoir. The ambient temperature was about $32^{\circ} \mathrm{C}$ with a relative humidity of $56 \%$. The speed of truck was about $60 \mathrm{~km} / \mathrm{h}$. As a result of providing the appropriate ventilation, the relative humidity in the crates was about $65 \%$ during the transport period. The birds were transported on S352 provincial highway in Dongtai District, Jiangsu, China. Upon arrival, broilers of the T group were removed from the truck and slaughtered immediately, broilers of the TR group were placed in a quiet area with an average temperature of $30^{\circ} \mathrm{C}$ for $1 \mathrm{~h}$ with a relative humidity of $60 \%$,

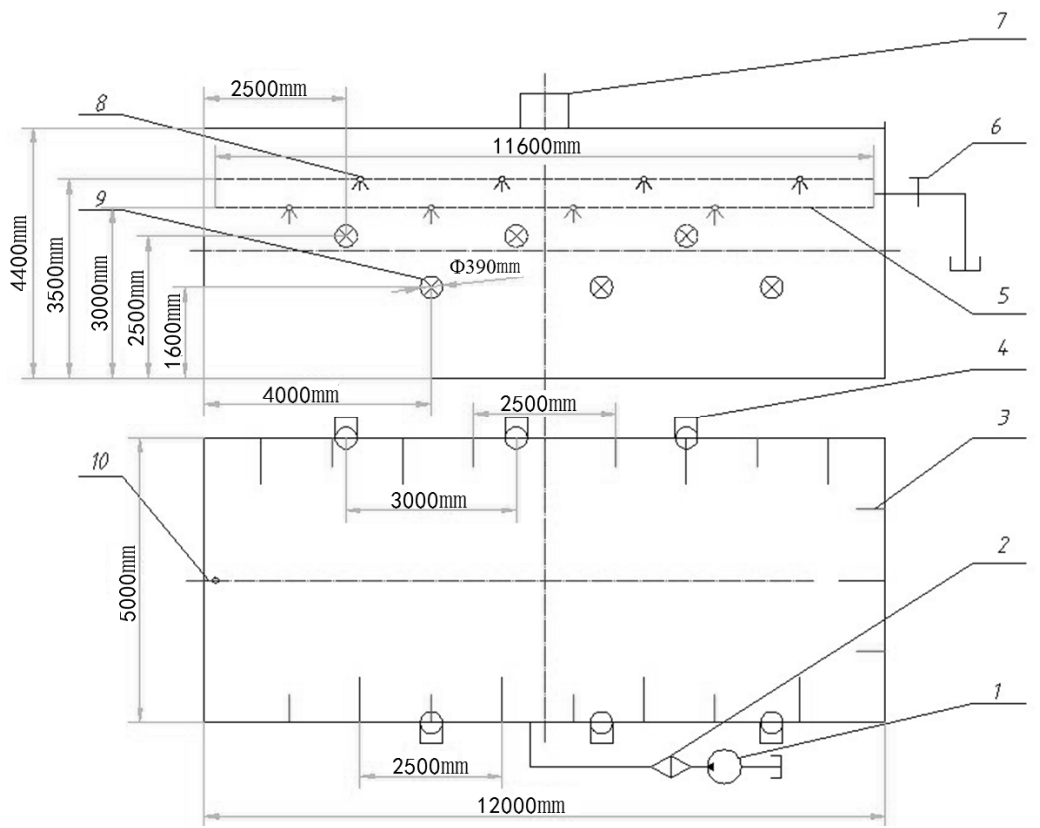

Figure 1. Schematic description of water-misting sprays with forced ventilation shed (1, pump; 2, filters; 3 and 8, sprinkle-nozzle; 4 and 9 , draught fan; 5 , waterpipe; 6 , pressure controlled valve; 7 , downdraught fan; 10 , temperature sensor). 
while the broilers of the TWFR group were put into the shed containing the water-misting sprays with forced ventilation and subjected to water-misting sprays with forced ventilation for $15 \mathrm{~min}$. The ambient temperature in the shed was $27^{\circ} \mathrm{C}$ with a relative humidity of $70 \%$.

\section{Sampling}

Blood plasma samples: All birds were stunned using an electrical stunner $(15 \mathrm{~V}$, alternating current; $750 \mathrm{~Hz}$ for $10 \mathrm{~s}$ each) and slaughtered within 5 min. Blood was collected in tubes containing heparinized anticoagulant during bleeding from the jugular vein and carotid artery and immediately mixed. The samples were then centrifuged (Avanti J-E, Beckman Coulter, Brea, CA, USA) at $2,000 \times \mathrm{g}$ at $4^{\circ} \mathrm{C}$ for 10 $\mathrm{min}$, and the plasma was removed and stored at $-80^{\circ} \mathrm{C}$ until required for the analysis of creatine kinase $(\mathrm{CK})$, lactate dehydrogenase (LDH) and glucose assessment.

Muscle samples: Immediately after slaughter, both pectoralis major (PM) muscle were removed (about $30 \mathrm{~min}$ postmortem), placed in zip-sealed plastic bags, and then kept at $4^{\circ} \mathrm{C}$ cooler overnight. Five grams muscle samples were stored in antifreeze tubes at $30 \mathrm{~min}$ and $24 \mathrm{~h}$ postmortem and quickly frozen in liquid nitrogen, and then stored at $-80^{\circ} \mathrm{C}$ until analysis. Muscle samples were collected from the left PM muscle for $\mathrm{pH}$, glycogen, and lactate test. The right PM muscle were used to measure meat color, drip loss, cook loss, light microscopy.

\section{Measurements}

Plasma parameters: Plasma CK, LDH activity, and glucose were measured with CK kit (Nanjing Jiancheng Bioengineering Institute, Nanjing, China), LDH activity kit (Nanjing Jiancheng Bioengineering Institute) and glucose oxidase kit (Nanjing Jiancheng Bioengineering Institute), respectively. Each blood sample was measured in triplicate according to the manufacturers' instructions.

Muscle $\mathrm{pH}$ : The $\mathrm{pH}$ of postmortem muscle at $30 \mathrm{~min}$ and $24 \mathrm{~h}$ was measured in meat homogenates according to McGeehin et al. (2001). For this, $0.5 \mathrm{~g}$ frozen sample was homogenized in $5 \mathrm{~mL}$ of ice-cold buffer containing sodium iodoacetate $(5 \mathrm{mM})$ and potassium chloride $(150 \mathrm{mM}), \mathrm{pH}$ 7.0 using an Ultra-Turrax T25 (IKA, Staufen, Germany) at $13,500 \mathrm{rpm}$ for $30 \mathrm{~s}$. The $\mathrm{pH}$ of the homogenate was recorded with a Mettler $\mathrm{pH}$ meter (FE-20, Mettler-Toledo Instruments Co., Ltd., Zurich, Switzerland).

Meat color: At $24 \mathrm{~h}$ after slaughter, meat color was measured on the cranial, medial surface (bone side) in triplicate using a chromameter (Minolta CR400, Konica Minolta Company, Tokyo, Japan). Color was reported in the CIE-Lab trichromatic system as lightness $\left(\mathrm{L}^{*}\right)$, redness $\left(\mathrm{a}^{*}\right)$ and yellowness $\left(b^{*}\right)$ values.

Drip loss: Each meat sample was trimmed into a specific shape $\left(1 \times 1 \times 3 \mathrm{~cm}^{3}\right)$ and weighed $\left(\mathrm{W}_{1}\right)$ precisely, then suspended on a hook from the lid of an air-tight container as described by Northcutt et al. (1994). Containers were stored for $24 \mathrm{~h}$ at $4^{\circ} \mathrm{C}$ and each sample was reweighed $\left(\mathrm{W}_{2}\right)$ to determine drip loss.

$$
\text { Drip loss }(\%)=\left(\mathrm{W}_{1}-\mathrm{W}_{2}\right) / \mathrm{W}_{1} \times 100 \%
$$

Cook loss: Cook loss was assessed using a modified procedure of Honikel (1998). About $30 \mathrm{~g}$ (wet weight) of regular-shaped muscle from PM was weighed $\left(\mathrm{W}_{3}\right)$ accurately and put into a thin-walled plastic bag and then cooked in an $80^{\circ} \mathrm{C}$ water bath until the internal temperature reached $75^{\circ} \mathrm{C}$. The bags were removed from the water bath and then put under tap water for $20 \mathrm{~min}$. Each muscle was reweighed $\left(\mathrm{W}_{4}\right)$.

$$
\text { Cook loss }(\%)=\left(\mathrm{W}_{3}-\mathrm{W}_{4}\right) / \mathrm{W}_{3} \times 100 \%
$$

Glycolytic potential measurement: Muscle glycogen and lactate content were determined by the method of Hambrecht et al. (2005). Briefly, a frozen muscle sample (1 g) at $30 \mathrm{~min}$ postmortem was homogenized (Ultra-Turrax T25) at 13,500 rpm for $30 \mathrm{~s}$ in $9 \mathrm{~mL}$ of ice-cold perchloric acid solution $\left(0.85 \mathrm{M} \mathrm{HClO}_{4}\right)$. The homogenates were centrifuged (Avanti J-E) at $2,700 \times \mathrm{g}$ at $4^{\circ} \mathrm{C}$ for $10 \mathrm{~min}$, and the supernatant fraction was neutralized with $10 \mathrm{M} \mathrm{KOH}$ and then stored in separate tubes at $-80^{\circ} \mathrm{C}$ for analysis. Lactate in the supernatant fraction was determined spectrophotometrically using a lactic acid kit (Nanjing Jiancheng Bioengineering Institute). Glycogen in the supernatant fraction was enzymically hydrolyzed to glucose by incubation with amyloglucosidase (A107823, AladdinPMI, Seattle, WA, USA) in acetate buffer ( $\mathrm{pH} 4.8)$ at $55^{\circ} \mathrm{C}$ for $2 \mathrm{~h}$. After incubation, the supernatant fraction was neutralized with $10 \mathrm{M} \mathrm{KOH}$. Glucose were determined spectrophotometrically using a commercial glucose oxidase kit (Nanjing Jiancheng Bioengineering Institute). The concentrations of glucose-6-phosphate and glucose were not determined individually, but included in the glycogen determination. The GP was calculated as the sum of $2 \times$ (glycogen)+(lactate) (Monin and Sellier, 1985).

Light microscopy: Light microscopy of muscle samples at $24 \mathrm{~h}$ postmortem was conducted as described by Barbut et al. (2005). All muscle sections $\left(2.0 \times 2.0 \times 0.5 \mathrm{~mm}^{3}\right)$ were cut along the direction of muscle fibers then placed in $10 \%$ formalin for $10 \mathrm{~h}$ to prefix the structure and then were dehydrated serially with $75 \%, 85 \%, 95 \%$, and $100 \%$ ethanol followed by xylene. Samples were then embedded in paraffin, cut into 4 to $6 \mu \mathrm{m}$ thick sections (Leica CM1900 Cryostat, Leica, Wetzlar, Germany; PowerTome XL, RMCBoeckeler, Tucson, AZ, USA) and transferred onto a glass slide. Slides were dried, stained with hematoxylin-eosin, and observed using a light microscope (Axio Scope.A1, 
Carl Zeiss, Oberkochen, Germany) at 20×magnification. Pictures were captured using a computerized image analysis system (Image-Pro Plus v4.5, Media Cybernetics Inc., Silver Spring, MD, USA).

\section{Statistical analysis}

All the data were subjected to a one-way ANOVA procedure provided in SAS 9.2 for Windows. Differences were determined by Duncan's multiple range tests. A significant difference was defined as $\mathrm{p}<0.05$ and the results are presented as mean \pm standard deviation.

\section{RESULTS AND DISCUSSION}

\section{Meat quality}

The effects of water-misting sprays with forced ventilation on meat quality of broilers after transport during summer are shown in Table 1. Compared with PM meat from the T and TR groups, meat from the TWFR group was significantly different for meat color lightness ( $\mathrm{L}^{*}$-value), drip loss, cook loss. However meat yellowness ( $b^{*}$-value) was not significantly different. The redness (a*-value) of breast muscle in group TWFR was lower $(p<0.05)$ than the $\mathrm{T}$ group. In addition, the breast muscle $\mathrm{pH}_{\mathrm{i}}$ (initial $\mathrm{pH}, \mathrm{pH}$ at 30 min postmortem) and $\mathrm{pH}_{\mathrm{u}}$ (ultimate $\mathrm{pH}, \mathrm{pH}$ at $24 \mathrm{~h}$ postmortem) in group TWFR was higher $(p<0.05)$ than the other groups. However, the $\Delta \mathrm{pH}\left(\mathrm{pH}_{\mathrm{u}}-\mathrm{pH}_{\mathrm{i}}\right)$ in TWFR group was lower $(\mathrm{p}<0.05)$ than the $\mathrm{T}$ group.

During summer, transport before slaughter may affect the postmortem metabolism of muscle, and cause variations in meat characteristics such as $\mathrm{pH}$, color, water holding capacity, and texture (Warriss et al., 1999). Color is an important meat quality attribute and is often used as an indicator of abnormal meat (PSE or dark, firm and dry [DFD]). Since the $\mathrm{L}^{*}$-value of PM muscle in the T group reached 53.10, the meat would be visually pale and classified as PSE-like according to the criterion of $24 \mathrm{~h} \mathrm{L*}$ - value greater than 53 (Qiao et al., 2002). McPhee and Trout (1995) found that the pigs that had been transported for short periods had a higher incidence of PSE meat. However the $\mathrm{L}^{*}$-value of PM muscles in the TWFR group was just 47.96, suggesting that water-misting sprays with forced ventilation after transport during summer had reduced stress and was beneficial for breast meat color. The present results supports that reported by Guarnieri et al. (2004) who found antemortem water shower treatment decreased lightness and inhibited PSE development in chicken breast muscle. However, in our study, water-misting sprays with forced ventilation after transport did not affect meat yellowness (b*-value).

Water-holding capacity is also an important meat quality attribute which can be estimated by determination of drip loss and cook loss. In the present study, drip loss of meat from the TWFR group was lower $(3.40 \%)$ compared with TR group $(5.18 \%)(p<0.05)$. Cook loss was also lower $(p<0.05)$ in TWFR samples $(12.71 \%)$ than TR samples $(15.71 \%)$. Thus this study shows that the use of watermisting sprays with forced ventilation after transport is beneficial for improving the water holding capacity of meat. De la Fuente et al. (2010) noted that at higher muscle $\mathrm{pH}$, proteins are able to bind more strongly with water, allowing less free water. In our study, the TWFR group had a higher $\mathrm{pH}$. Moreover, we found a lower drip loss and cook loss in muscle samples of TWFR group, which was similar with the findings of Guarnieri et al. (2004).

The ultimate $\mathrm{pH}$ of muscle is a major determinant of meat quality. The decline in muscle $\mathrm{pH}$ is due to an accumulation of lactic acid caused by postmortem glycolysis (Lawrie, 1998). Lactic acid production is dependent upon the content of glycogen at slaughter, as it is the substrate in glycolysis (Lawrie, 1998). The current study showed that broilers subjected to water-misting sprays with forced ventilation had raised $\mathrm{pH}_{\mathrm{i}}$ and $\mathrm{pH}_{\mathrm{u}}$ values and decreased $\Delta \mathrm{pH}$ values and a reduced rate of postmortem

Table 1. Effects of water-misting sprays with forced ventilation after transport during summer on breast meat quality of broilers $(n=35$ each treatment group)

\begin{tabular}{lrrrr}
\hline \multirow{2}{*}{ Item } & \multicolumn{3}{c}{ Treatment group } & p-value \\
\cline { 2 - 4 } & \multicolumn{1}{c}{$\mathrm{T}$} & \multicolumn{1}{c}{ TR } & \multicolumn{1}{c}{ TWFR } & $<0.0001$ \\
$\mathrm{~L}^{*}$ & $53.10 \pm 1.87^{\mathrm{a}}$ & $51.05 \pm 1.64^{\mathrm{b}}$ & $47.96 \pm 1.41^{\mathrm{c}}$ & $<0.0100$ \\
$\mathrm{a}^{*}$ & $5.41 \pm 1.40^{\mathrm{a}}$ & $4.63 \pm 0.96^{\mathrm{ab}}$ & $3.63 \pm 0.32^{\mathrm{b}}$ & 0.15910 \\
$\mathrm{~b}^{*}$ & $2.15 \pm 0.52^{\mathrm{a}}$ & $1.94 \pm 0.97^{\mathrm{a}}$ & $1.50 \pm 0.31^{\mathrm{a}}$ & $<0.0001$ \\
Drip loss (\%) & $6.88 \pm 1.26^{\mathrm{a}}$ & $5.18 \pm 0.64^{\mathrm{b}}$ & $3.40 \pm 0.38^{\mathrm{c}}$ & 0.0183 \\
Cook loss (\%) & $16.42 \pm 3.41^{\mathrm{a}}$ & $15.71 \pm 2.57^{\mathrm{a}}$ & $12.71 \pm 0.94^{\mathrm{b}}$ & $<0.0001$ \\
$\mathrm{pH}_{\mathrm{i}}$ & $6.25 \pm 0.04^{\mathrm{c}}$ & $6.30 \pm 0.05^{\mathrm{b}}$ & $6.39 \pm 0.05^{\mathrm{a}}$ & $<0.0001$ \\
$\mathrm{pH}_{\mathrm{u}}$ & $5.67 \pm 0.04^{\mathrm{c}}$ & $5.75 \pm 0.03^{\mathrm{b}}$ & $5.90 \pm 0.04^{\mathrm{a}}$ & $0.02 \pm 0.08^{\mathrm{b}}$ \\
$\Delta \mathrm{pH}$ & $0.58 \pm 0.04^{\mathrm{a}}$ & $0.55 \pm 0.06^{\mathrm{ab}}$ & $0.49 \pm 0$ & 0.02480 \\
\hline
\end{tabular}

Values are presented as mean \pm standard deviation.

T group, 45-min transport group; TR group, 45-min transport with 1-h rest; TWFR group, 45-min transport with 15-min water-misting sprays with forced ventilation and 45-min rest; $\mathrm{pH}_{\mathrm{i}}$, initial $\mathrm{pH}\left(\mathrm{pH}\right.$ at 30 min postmortem); $\mathrm{pH}_{\mathrm{u}}$, ultimate $\mathrm{pH}\left(\mathrm{pH}\right.$ at $24 \mathrm{~h}$ postmortem); $\Delta \mathrm{pH}, \mathrm{pH}_{\mathrm{u}}-\mathrm{pH}_{\mathrm{i}}$.

${ }^{a, b, c}$ Means within the same row with no common superscript differ significantly $(\mathrm{p}<0.05)$. 
glycolysis rate compared with other groups.

\section{Plasma parameters}

Effects of water-misting sprays with forced ventilation after transport on stress parameters in broilers are shown in Table 2. The CK activity decreased $(\mathrm{p}<0.05)$ in the TWFR group when compared with the other groups, with the $\mathrm{T}$ group having the highest $\mathrm{CK}$ activity. However, no significant differences were found in CK activity between the T and TR groups; similar trend was found for the glucose contents, where the TWFR group was lower $(p<0.05)$ than other two groups. LDH activities of the three groups were different $(\mathrm{p}<0.05)$; however the LDH activity in the TWFR group was the lowest.

Blood components, such as $\mathrm{CK}$, LDH, corticosterone, have been proposed as sensitive indicators of stress in animals (Mitchell and Sandercock, 1995; Yu et al., 2007). In response to muscle damage or vigorous exercise, $\mathrm{CK}$ is released into the blood (Mitchell and Sandercock, 1995). In the current study, the CK activity was $4.91 \mathrm{U} / \mathrm{mL}$ after transport, however it decreased significantly after application of water-misting sprays with forced ventilation, indicating such a process was beneficial for relieving the stress caused by transport and high temperature. Under normal circumstances, LDH does not readily enter the blood due to the barrier of the muscle cell membrane. Once the LDH activity increases in the plasma, it may indicate muscle damage and result from disruption of muscle cell membrane (sarcolemma) function and increased permeability (Fàbrega et al., 2002). In the present study, although the TR group had significantly reduced plasma LDH activity, the TWFR group was lower (3.41 vs 2.45; $\mathrm{p}<0.05)$. Glucose is an essential cellular fuel source and metabolic substrate (Zhang et al., 2009). Transport stress has been reported to cause an elevation in plasma glucose concentration, primarily due to glycogen breakdown in the liver (Mayes, 1996). In our study, plasma glucose concentration was not affected by resting ( $\mathrm{p}>0.05$ ), but water-misting sprays with forced ventilation did result in a reduction $(\mathrm{p}<0.05)$. Although there was an indication from plasma LDH data that the stress had been reduced, a lack of
Table 2. Effects of water-misting sprays with forced ventilation after transport during summer on CK, LDH activity and plasma glucose content of broilers $(\mathrm{n}=35$ each treatment group)

\begin{tabular}{lccc}
\hline \multirow{2}{*}{ Item } & \multicolumn{3}{c}{ Treatment group } \\
\cline { 2 - 4 } & $\mathrm{T}$ & $\mathrm{TR}$ & TWFR \\
\hline $\mathrm{CK}(\mathrm{U} / \mathrm{mL})$ & $4.91 \pm 0.63^{\mathrm{a}}$ & $4.61 \pm 0.52^{\mathrm{a}}$ & $3.40 \pm 0.67^{\mathrm{b}}$ \\
$\mathrm{LDH}(\mathrm{U} / \mathrm{mL})$ & $3.87 \pm 0.62^{\mathrm{a}}$ & $3.41 \pm 0.17^{\mathrm{b}}$ & $2.45 \pm 0.28^{\mathrm{c}}$ \\
Glucose $(\mathrm{mmol} / \mathrm{L})$ & $22.25 \pm 0.99^{\mathrm{a}}$ & $21.69 \pm 1.81^{\mathrm{a}}$ & $18.85 \pm 2.09^{\mathrm{b}}$ \\
\hline
\end{tabular}

Values are presented as mean \pm standard deviation.

T group, 45-min transport group; TR group, 45-min transport with 1-h rest; TWFR group, 45-min transport with 15 -min water-misting sprays with forced ventilation and 45-min rest; $\mathrm{CK}$, creatine kinase; $\mathrm{LDH}$, lactate dehydrogenase.

a,b,c Means within the same row with no common superscript differ significantly $(\mathrm{p}<0.05)$

differences in plasma $\mathrm{CK}$ activities and glucose contents suggests that rest alone after transport was not as effective as water-misting with forced ventilation. Therefore watermisting with forced ventilation is a suggested method to improve animal welfare.

\section{Early postmortem muscle metabolism}

The effects of water-misting sprays with forced ventilation after transport on GP in the PM muscle at early postmortem are shown in Table 3. For broilers slaughtered immediately after transport ( $\mathrm{T}$ group), the glycogen content of muscle was $26.19 \mu \mathrm{mol} / \mathrm{g}$ and was higher $(\mathrm{p}=0.0085)$ than that from those that had been rested (TR group) and those that had been subjected to water misting and forced ventilation. Compared with the $\mathrm{T}$ and $\mathrm{TR}$ groups, the TWFR group was significantly different for lactate and GP. Although the glycogen content of the TWFR was not different from the TR group ( $p>0.05)$, the lactate content of the TWFR group was lower $(p<0.05)$ than the TR group; similar trend was found for GP, where the TWFR group was lower $(\mathrm{p}<0.05)$ than the TR group.

Preslaughter stress causes the depletion of glycogen reserves from skeletal muscles (Savenije et al., 2002). Postmortem metabolism of intramuscular energy stores (glycogen) plays a primary role in the conversion of muscle to meat. Loss of blood circulation at death causes

Table 3. Effects of water-misting sprays with forced ventilation after transport during summer on GP in the PM muscle at early postmortem $(n=35$ each treatment group $)$

\begin{tabular}{lrrrr}
\hline \multirow{2}{*}{ Item } & \multicolumn{3}{c}{ Treatment group } & \multirow{2}{*}{ p-value } \\
\cline { 2 - 4 } & \multicolumn{1}{c}{$\mathrm{T}$} & $\mathrm{TR}$ & TWFR & 0.0085 \\
Glycogen $^{1}(\mu \mathrm{mol} / \mathrm{g})$ & $26.19 \pm 2.59^{\mathrm{a}}$ & $23.40 \pm 0.26^{\mathrm{b}}$ & $24.45 \pm 1.92^{\mathrm{b}}$ & $<0.0001$ \\
Lactate $(\mu \mathrm{mol} / \mathrm{g})$ & $79.89 \pm 1.74^{\mathrm{a}}$ & $76.32 \pm 0.49^{\mathrm{b}}$ & $69.75 \pm 2.09^{\mathrm{c}}$ & $<0.0001$ \\
GP $(\mu \mathrm{mol} / \mathrm{g})$ & $132.27 \pm 5.32^{\mathrm{a}}$ & $123.12 \pm 0.64^{\mathrm{b}}$ & $118.65 \pm 5.03^{\mathrm{c}}$ & \\
\hline
\end{tabular}

Values are presented as mean \pm standard deviation.

T group, 45-min transport group; TR group, 45-min transport with 1-h rest; TWFR group, 45-min transport with 15-min water-misting sprays with forced ventilation and 45-min rest; GP, glycolytic potential; PM, pectoralis major.

${ }^{\mathrm{a}, \mathrm{b}, \mathrm{c}}$ Means within the same row with no common superscript differ significantly $(\mathrm{p}<0.05)$.

${ }^{1}$ Includes glucose, glucose-6-phosphate, and glycogen. 
postmortem glycolysis to occur in an anaerobic state resulting in a build up of lactic acid (Lawrie, 1998) which is responsible for decline in muscle $\mathrm{pH}$. In present study, we found GP of $\mathrm{T}$ group was higher than the other groups. Previous studies had shown that high GP in meat is associated with a faster $\mathrm{pH}$ decline, low ultimate $\mathrm{pH}$ (Bertol et al., 2005), and high drip loss and lighter color (high $\mathrm{L}^{*}$ value) (Hambrecht et al., 2004). Similar results were found in our study where water-misting sprays with forced ventilation after transport had a better effect on GP. As the water-misting sprays with forced ventilation after transport changed the microenvironment (temperature $=27^{\circ} \mathrm{C}$, the relative humidity $=70 \%$ ) and created a better environment for the recovery of broilers. The lactic acid accumulated more slowly in the TWFR group, indicating a decrease in glycolysis rate which had a positive influence on meat quality. Generally, transport causes a significantly increase in glycolysis rate. However, an appropriate rest, especially combined with water-misting sprays with forced ventilation, was able to reduce the negative effects of transport-induced stress by decreasing the muscle lactate concentration and GP, which then improve animal welfare and meat quality.

\section{Microstructure}

The microstructure images (Figure 2) show morphological differences among the T, TR, TWFR groups. Where the broilers were slaughtered immediately after transport without resting, the muscle showed a loose arrangements of muscle fiber bundles (Figure 3A), indicative of expelled fluid. With rest (TR) and particularly with water spraying with forced ventilation (TWFR), there was clear evidence of less muscle shrinkage (Figure 3B and $3 \mathrm{C}$ ), where the latter shows a dense and compact microstructure. From the Figure $3 \mathrm{C}$, we can see that the muscle fibers of the TWFR group had almost entirely filled the endomysial space and muscle bundles had filled the perimysium. Offer and Cousins (1992) observed gap formation between fiber bundles and the perimysial network in some muscles and concluded that the fluid was expelled due to myofibrillar shrinkage and then accumulated in the extracellular spaces. The average cell diameter of $\mathrm{T}$ group was smaller $(\mathrm{p}<0.05)$ in comparison to the TWFR group ( 42.73 vs 53.01 , data not shown). The $\mathrm{T}$ group had the highest GP which indicated rapid glycolysis. The rapid postmortem glycolysis with high temperature could cause protein denaturation which could cause water loss. The reason that caused the muscle cells shrunk was a loss of water. Thus the water moves from the myofibrillar to interfibrillar compartments then to the extracellular compartments and finally drip is formed on the meat surface giving the watery appearance (Guarnieri et al., 2004). Offer (1984) suggested that the fluid collected in these wide channels might be source of drip loss, which

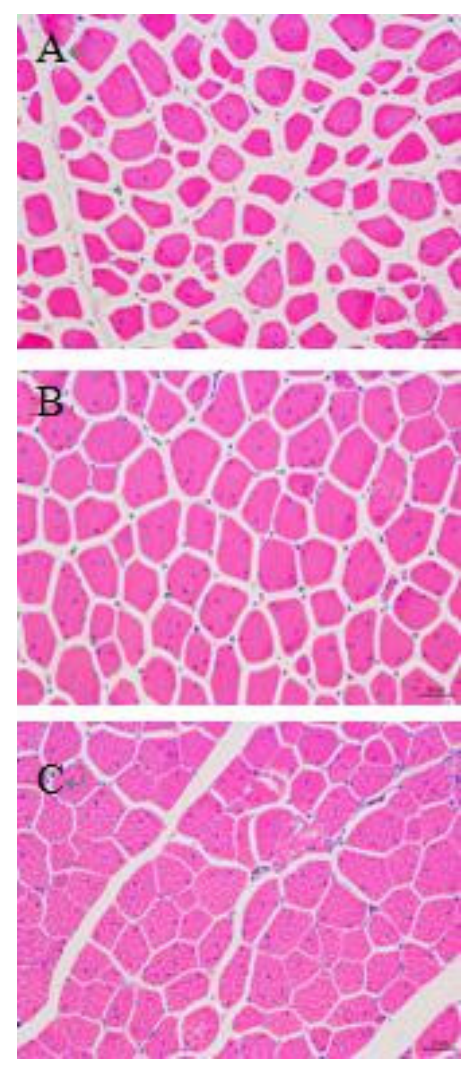

Figure 2. Representative micrographs from light microscopy of transvers sections of skeletal muscle of broiler breast meat at $24 \mathrm{~h}$ postmortem (A, B, C). Different treatments were as follows. (A) T group, 45-min transport group. (B) TR group, 45-min transport with 1-h rest. (C) TWFR group, 45-min transport with 15-min water-misting sprays with forced ventilation and 45-min rest.

could explain the significantly higher drip loss from the $\mathrm{T}$ group meat than from the TWFR group meat.

\section{CONCLUSION}

The results indicated that water-misting sprays with forced ventilation after transport could relieve the stress caused by transport under high temperature during summer, which is favorable for the broilers' welfare. Furthermore, water-misting sprays with forced ventilation after transport could slow down postmortem glycolysis, then decreased the lightness, improved the water holding capacity in breast meat, and thus, lowered the occurrence of PSE-like meat in broilers. Although rest after transport could also improve the meat quality, the effect was not as significant as watermisting sprays with forced ventilation after transport.

\section{CONFLICT OF INTEREST}

We certify that there is no conflict of interest with any financial organization regarding the material discussed in the manuscript. 


\section{ACKNOWLEDGMENTS}

This work was supported by the China Agriculture Research System (CARS-42), National Key Technology Research and Development Program of the Ministry of Science (31101308 and 31171707) and National Key Technology Research and Development Program of China during the 10th Five-Year Plan (2012BAD28B01).

\section{REFERENCES}

Barbut, S., L. Zhang, and M. Marcone. 2005. Effects of pale, normal, and dark chicken breast meat on microstructure, extractable proteins, and cooking of marinated fillets. Poult. Sci. 84:797-802.

Bertol, T. M., M. Ellis, M. J. Ritter, and F. K. McKeith. 2005. Effect of feed withdrawal and handling intensity on longissimus muscle glycolytic potential and blood measurements in slaughter weight pigs. J. Anim. Sci. 83:15361542 .

Daghir, N. J. 2009. Nutritional strategies to reduce heat stress in broilers and broiler breeders. Lohmann Inf. 44:6-15.

De la Fuente, J., M. Sánchez, C. Pérez, S. Lauzurica, C. Vieira, E. González de Chávarri, and M. T. Díaz. 2010. Physiological response and carcass and meat quality of suckling lambs in relation to transport time and stocking density during transport by road. Animal 4:250-258.

Fàbrega, E., X. Manteca, J. Font, M. Gispert, D. Carrión, A. Velarde, J. L. Ruiz-de-la-Torre, and A. Diestre. 2002. Effects of halothane gene and pre-slaughter treatment on meat quality and welfare from two pig crosses. Meat Sci. 62:463-472.

Fazio, E. and A. Ferlazzo. 2003. Evaluation of stress during transport. Vet. Res. Commun. 27:519-524.

Guarnieri, P. D., A. L. Soares, R. Olivo, J. P. Schneider, R. M. Macedo, E. I. Ida, and M. Shimokomaki. 2004. Preslaughter handling with water shower spray inhibits PSE (Pale, Soft, Exudative) broiler breast meat in a commercial plant: Biochemical and ultrastructural observations. J. Food Biochem. 28:269-277.

Hambrecht, E., J. J. Eissen, D. J. Newman, C. H. M. Smits, M. W. A. Verstegen, and L. A. Den Hartog. 2005. Preslaughter handling effects on pork quality and glycolytic potential in two muscles differing in fiber type composition. J. Anim. Sci. 83:900-907.

Hambrecht, E., J. J. Eissen, R. I. J. Nooijen, B. J. Ducro, C. H. M Smits, L. A. Den Hartog, and M. W. A. Verstegen. 2004 Preslaughter stress and muscle energy largely determine pork quality at two commercial processing plants. J. Anim. Sci. 82:1401-1409.

Honikel, K. O. 1998. Reference methods for the assessment of physical characteristics of meat. Meat Sci. 49:447-457.

Lawrie, R. A. 1998. Lawry's Meat Science. 6th Ed. Woodhead Publishing, Cambridge, UK.

Mayes, P. A. and D. A. Bender. 1996. Gluconeogenesis and control of blood glucose. In: Harper's Biochemistry, 24th Ed. (Eds. R. K. Murray, D. K. Granner, P. A. Mayers, and V. W. Rodwell). Appleton \& Lange, Stamford, CT, USA. pp. 153-162.
McGeehin, B., J. J. Sheridan, and F. Butler. 2001. Factors affecting the $\mathrm{pH}$ decline in lamb after slaughter. Meat Sci. 58:79-84.

McPhee, C. P. and G. R. Trout. 1995. The effects of selection for lean growth and the halothane allele on carcass and meat quality of pigs transported long and short distances to slaughter. Livest. Prod. Sci. 42:55-62.

Mitchell, M. A. and D. A. Sandercock. 1995. Creatine kinase isoenzyme profiles in the plasma of the domestic fowl (Gallus domesticus): Effects of acute heat stress. Res. Vet. Sci. 59:3034.

Mitchell, M. A. and P. J. Kettlewell. 2009. Welfare of poultry during transport: a review. In: Proceedings of the 8th European Symposium on Poultry Welfare, Cervia, Italy. pp. 90-100.

Monin, G. and P. Sellier. 1985. Pork of low technological quality with a normal rate of muscle $\mathrm{pH}$ fall in the immediate postmortem period: The case of the Hampshire breed. Meat Sci. 13:49-63.

Northcutt, J. K., E. A. Foegeding, and F. W. Edens. 1994. Waterholding properties of thermally preconditioned chicken breast and leg meat. Poult. Sci. 73:308-316.

Offer, G. 1984. Progress in the biochemistry, physiology and structure of meat. In: Proceedings of the 30th European Meeting of Meat Research Workers, Bristol, UK. pp. 87-94.

Offer, G. and T. Cousins. 1992. The mechanism of drip production: formation of two compartments of extracellular space in muscle post mortem. J. Sci. Food Agric. 58:107-116.

Qiao, M., D. L. Fletcher, J. K. Northcutt, and D. P. Smith. 2002. The relationship between raw broiler breast meat color and composition. Poult. Sci. 81:422-427.

Sams, A. R. 1999. Meat quality during processing. Poult. Sci. 78:798-803.

Savenije, B., E. Lambooij, M. A. Gerritzen, K. Venema, and J. Korf. 2002. Effects of feed deprivation and transport on preslaughter blood metabolites, early postmortem muscle metabolites, and meat quality. Poult. Sci. 81:699-708.

Turner, L. W., H. J. Monegue, R. S. Gates, and M. D. Lindemann. 1997. Fan, sprinkler, and sprinkler plus fan systems for cooling growing-finishing swine. In: Proceedings of the American Society of Agricultural Engineers (ASAE) Annual International Meeting, Minneapolis, MN, USA.

Warriss, P. D., L. J. Wilkins, and T. G. Knowles. 1999. The influence of ante-mortem handling on poultry meat quality. In: Poultry Meat Science: The 25th Poultry Science Symposium (Eds. R. I. Richardson and G. C. Mead). CABI Publishing, Wallingford, UK. pp. 217-230.

Yu, H., E. D. Bao, R. Q. Zhao, and Q. X. Lv. 2007. Effect of transportation stress on heat shock protein 70 concentration and mRNA expression in heart and kidney tissues and serum enzyme activities and hormone concentrations of pigs. Am. J. Vet. Res. 68:1145-1150.

Yunis, R. and A. Cahaner. 1999. The effects of the naked neck $(\mathrm{Na})$ and frizzle $(\mathrm{F})$ genes on growth and meat yield of broilers and their interactions with ambient temperatures and potential growth rate. Poult. Sci. 78:1347-1352.

Zhang, L., H. Y. Yue, H. J. Zhang, L. Xu, S. G. Wu, H. J. Yan, Y. S. Gong, and G. H. Qi. 2009. Transport stress in broilers: I. Blood metabolism, glycolytic potential, and meat quality. Poult. Sci. 88:2033-2041 